
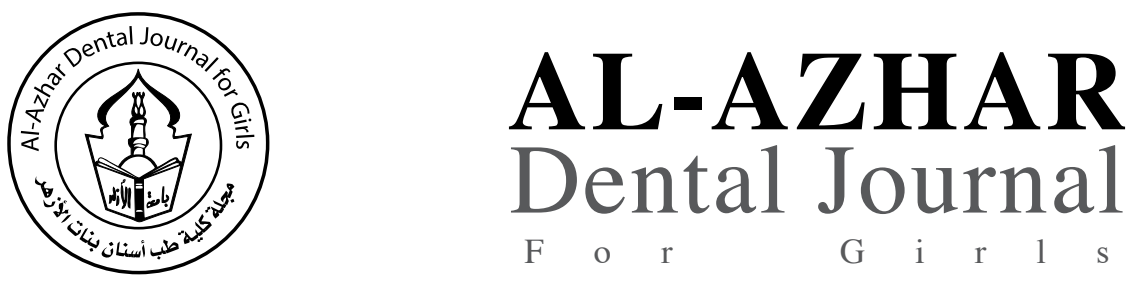

The Official Publication of The Faculty of Dental Medicine For Girls,

Al-Azhar University Cairo, Egypt.

ADJ-for Grils, Vol. 4, No. 3, July (2017) — PP. 255:270

\title{
The Effect of Various Elements Substitution on Properties of Bioactive Glass Scaffolds for Bone Tissue Engineering.
}

\author{
Fatma Alzhraa M. Abdul-Rahman ${ }^{(1)}$, Inas T. M. Motawea ${ }^{(2)}$ and Eatimad A. Shoreibah $^{(3)}$
}

Codex : 31/1707

dentaljournal.forgirls@yahoo.com

\begin{abstract}
Aim: The aim of the present study was to synthesize and characterize sol-gel derived bioactive glass scaffold and evaluate the effect of substitution of Zirconium ( $\mathrm{Zr}$ ), Strontium (Sr), and Zinc (Zn) on the their bioactivity, biodegradability and mechanical properties. Materials and Methods: Bioactive glass scaffold samples with compositions $80 \% \mathrm{SiO}_{2}-15 \% \mathrm{CaO}$ and $5 \% \mathrm{P}_{2} \mathrm{O}_{5}$ and $75 \% \mathrm{SiO}_{2}-15 \% \mathrm{CaO}-5 \% \mathrm{P}_{2} \mathrm{O}_{5}$ and $5 \% \mathrm{MO}$ (in $\mathrm{mol} \%)(\mathrm{M}=\mathrm{Sr}, \mathrm{Zr}$ or $\mathrm{Zn}$ ) were synthesized using the sol-gel combined with foam replication method. The scaffolds were characterized by DTA, XRD, SEM and FTIR spectroscopy. Their mechanical properties were measured and their bioactivity/ biodegradability were evaluated in simulating body fluid (SBF). Results: All the scaffolds showed no distinct difference in phase composition, macroporous structure, percent porosity or pore size distribution. Conclusions: $\mathrm{Sr}, \mathrm{Zr}$ and $\mathrm{Zn}$ substitution decreased the mechanical properties of the bioglass system. Sr and $\mathrm{Zr}$ ions enhanced the formation of nano-structured hydroxycarbonate apatite (HCA) layer, whereas $\mathrm{Zn}$ ions diminished the bioactivity. Moreover, Sr ions increased the biodegradability of the bioglass system.
\end{abstract}

\section{INTRODUCTION}

Bioactive glasses are considered one of the most promising scaffold materials for bone regeneration since their discovery due to their versatile properties, which can be properly designed depending on their composition ${ }^{(1)}$. They have superior osteoconductivity, controlled biodegradability, cell delivery capabilities, the capacity for activation of osteogenic gene expression. They also favor the formation of bone mineral-like phases and have drug delivery abilities, mainly stemming from their composition, which is similar to bone mineral ${ }^{(1,2)}$.

1. Assistant Lecturer of Dental Biomaterials, Faculty of Dental Medicine for Girls, Al-Azhar University.

2. Assistant Professor and Head of Dental Biomaterials Department, Faculty of Dental Medicine for Girls, Al- Azhar University.

3. Professor of Oral Medicine \& Periodontology, Faculty of Dental Medicine for Girls, Al-Azhar University. 
The bioactive glasses invention led to a revolution in the development of biomaterials and doped system of bioglasses for the human body. Most current researches focus on changing the structure of the bioactive glass system to make the material more compatible for different clinical applications. This can be achieved through adding or removing ions and upon changing the processing conditions that is melt quenching or sol-gel ${ }^{(1,3)}$.

A bioactive material has been defined as a material that undergoes specific surface reactions, when implanted into the body, leading to the formation of an HA-like layer that is responsible for the formation of a chemical bond with hard and soft tissues preventing the formation of fibrous tissue ${ }^{(4)}$.

In late 1960s, Professor Larry Hench - the pioneer of bioactive glass, discovered biomedical applications of glass by developing the wellknown 45S5 Bioglass with his colleagues that was successfully marketed worldwide as a bonereplacement material ${ }^{(5)}$. However, the advantages of bioactive glasses over other bioceramics are the speed of their surface reactivity in vitro and in vivo and the ability to alter the chemical composition ${ }^{(6)}$. The bioactive silicate glasses pioneered the current era of bioactive materials owing to the importance of silicon in bone development. Considerable research $^{(7)}$ has subsequently focused on the chemistry and biological function of silicon in bone, demonstrating that the element has obvious effects in extracellular and on the molecular biology of osteoblasts in vitro.

Paper extracted from doctor thesis entitled 'The Effect of Various Elements Substitution on Properties of Bioactive Glass Scaffolds for Bone Tissue Engineering"

Furthermore, Silica is attracting attention of researchers in the field of nanomedicine and drug delivery ${ }^{(8)}$.

In order to enhance the bioactivity, and/or biodegradability of bioactive glasses towards a specific biological response in relevant physiological environments, many approaches have been investigated incorporating various metal ions "dopants" in the glass network ${ }^{(9)}$. Cupper ions are proved to play an important role in mesoporous bioglass MBG scaffold system offering multifunctional properties through combining angiogenesis capacity, osteostimulation, and antibacterial properties for regenerating lost bone tissues ${ }^{(10)}$. A recent approach utilizing containerless processing (CP) technique and sol-gel (SG) method to design $\mathrm{Ca}-\mathrm{Sr}-\mathrm{Si}$ biomaterials with controllable ion release was provided ${ }^{(11)}$. The effect of cerium and gallium substitution on improving the in vitro bioactivity of the prepared BG fibers was assessed $^{(12)}$. Multifunctional bioactive Hardystonite (HT) iron-containing scaffolds (Fe-HT) were prepared to achieve hyperthermia and local drug delivery that proposed as potential therapeutic approaches for killing cancer cells ${ }^{(13)}$. One of the major challenges of tissue engineering has been concerned with the design and development of bioactive materials and their biodegradability after performing their function so that the tissue can be remodeled to its natural form. Due to the diversity of the studied bioglass systems and difference in concentrations of the substituted ions, it is difficult to state that $\mathrm{Zn}, \mathrm{Sr}$ or $\mathrm{Zr}$ improves or retards glass bioactivity in general. Hence, it is important to get insight into the bioglass and to have a structural understanding of each substituted cations within the glass.

\section{MATERIALS AND METHODS}

A total of one hundred bioactive glass scaffold samples were synthesized by sol-gel method. The samples were divided into four groups $(n=25)$ regarding the type of substituting ion. Group1; was prepared with no ion substitution to serve as a control group. The glass composition (in mol\%) was $80 \%$ silicon dioxide $\left(\mathrm{SiO}_{2}\right)-5 \%$ phosphorous pentoxide $\left(\mathrm{P}_{2} \mathrm{O}_{5}\right)-15 \%$ calcium oxide $(\mathrm{CaO})$ $(83,105)$ for the control group; named (BG). Groups 
(2,3 and 4$) ; 5 \mathrm{~mol} \%$ of zinc oxide $(\mathrm{ZnO})$, zirconium oxide $\left(\mathrm{ZrO}_{2}\right)$, and srontium oxide $(\mathrm{SrO})$ were used to substitute $5 \mathrm{~mol} \%$ of $\mathrm{SiO}_{2}$. They were labeled regarding the substituting element i.e. $\mathrm{Zn}-\mathrm{BG}, \mathrm{Zr}$ $\mathrm{BG}$ and Sr-BG, respectively. The nominal molar compositions of the different groups are shown in Table (1).

Each group was further subdivided into 5 subgroups ( $n=5)$ according to the method of testing (porosity measurement, mechanical testing and testing of bioactivity and biodegradability). One sample was used to study the thermal properties and another sample was used for structural characterization. Subgroup 1; samples (15 x 10 $\mathrm{mm}$ ) were used to measure the percent porosity. Subgroup 2; samples (10 x 10 x $5 \mathrm{~mm})$ were subjected to compression test, Subgroup 3; samples (15 $\mathrm{mm}$ diameter $\mathrm{x} 10 \mathrm{~mm}$ length) were subjected to indirect tensile test. Subgroup 4; samples (15 x 10 $\mathrm{mm}$ ) were used to assess the bioactivity. Subgroup 5; samples $(15 \times 10 \mathrm{~mm})$ were used to assess the biodegradability; where two samples from those used in bioactivity test were also used for the assessment of biodegradability.

\section{Bioglass scaffolds preparation by sol-gel method combined with foam replication method:}

Bioactive glass scaffolds with composition $80 \% \mathrm{SiO}_{2}-15 \% \mathrm{CaO}$ and $5 \% \mathrm{P}_{2} \mathrm{O}_{5}$ and $75 \% \mathrm{SiO}_{2}-$ $15 \% \mathrm{CaO}-5 \% \mathrm{P}_{2} \mathrm{O}_{5}$ and $5 \%$ substituting element oxide ( $\mathrm{Zn}, \mathrm{Zr}$ or $\mathrm{Sr}$ ) were synthesized using the nonionic block copolymer (P123, Mw 5800) and polyurethane foams as cotemplates. In atypical synthesis, tetraethyl orthosilicate(TEOS), a certain amount of divalent cation nitrates, $\mathrm{M}\left(\mathrm{NO}_{3}\right)_{2}(\mathrm{M}=$ $\mathrm{Ca}, \mathrm{Zr}, \mathrm{Zn}$ and $\mathrm{Sr}$ ) and triethyl phosphate (TEP) were dissolved in $76 \mathrm{~mL}(60 \mathrm{~g})$ of ethanol mixed with $1.075 \mathrm{~mL}$ of $0.5 \mathrm{~N}$ nitric acid. After the addition of P123 (4 g), the ethanol solution was stirred by magnetic stirrer (VELP Scientifica, ARE2, Italy) at room temperature for $1 \mathrm{~h}$ to obtain the bioglass $\operatorname{sol}^{(14,15)}$.
Table (1): Glass compositions (mol\%) in different groups

\begin{tabular}{|c|c|c|c|c|c|c|}
\hline Groups & $\stackrel{0}{n}^{N}$ & $\begin{array}{l}O^{n} \\
a^{n}\end{array}$ & U్ & $\begin{array}{l}\text { O } \\
\text { N }\end{array}$ & $\stackrel{0}{N}^{N}$ & $\stackrel{0}{\stackrel{D}{\infty}}$ \\
\hline Group 1 (BG) & 80 & 5 & 15 & - & - & - \\
\hline Group 2 (Zn-BG) & 75 & 5 & 15 & 5 & - & - \\
\hline Group 3 (Zr-BG) & 75 & 5 & 15 & - & 5 & - \\
\hline Group 4 (Sr-BG) & 75 & 5 & 15 & - & - & 5 \\
\hline
\end{tabular}

Afterward, the polyurethane foams were completely immersed in the sol for $10 \mathrm{~min}$. Excess sol on the sponges was then squeezed out. The foams were uniformly coated with an appropriate amount of sol and compressed, to force the sol to migrate into the pores of the foam. Then the foams were pressed to squeeze out the excess sol. After that, the foams were dried at room temperature for $12 \mathrm{~h}$ in air. The same procedure was repeated 8 times to obtain raw porous bodies of $\mathrm{CaO}-\mathrm{MO}-\mathrm{SiO}_{2}-\mathrm{P}_{2} \mathrm{O}_{5}$ gel on polyurethane foam ${ }^{(16)}$. All the samples were calcined at $700{ }^{\circ} \mathrm{C}\left(2^{\circ} \mathrm{C} / \mathrm{min}\right)$ for $8 \mathrm{~h}$ to obtain the final bioglass scaffolds.

The SBF solution was prepared by dissolving reagent-grade $\mathrm{Na} \mathrm{Cl}, \mathrm{KCl}, \mathrm{Na} \mathrm{HCO} 3, \mathrm{Mg} \mathrm{Cl} 2$. $6 \mathrm{H} 2 \mathrm{O}, \mathrm{Ca} \mathrm{Cl} 2$ and $\mathrm{KH} 2 \mathrm{PO} 4$ into distilled water and buffered at $\mathrm{pH}=7.4$ with TRIS (tris-hydroxymethyl aminomethane) and $\mathrm{HCl}$ at $37{ }^{\circ} \mathrm{C}$ according to Kokubo's method ${ }^{(17)}$.

\section{Characterization of bioglass samples:}

Thermal analysis of the glass systems were studied by thermo-gravimetric and differential thermal analysis instrument (TGA/DTA) (STA 409 Netzsch instrument) through heating $70 \mathrm{mg}$ of PU foam loaded with bioglass sol of each group (10 ${ }^{\circ} \mathrm{C} / \mathrm{min}$ ) under $\mathrm{N}_{2}$ atmosphere up to $1000{ }^{\circ} \mathrm{C}^{(18)}$. Structural analysis of the bioglass powder of each group, obtained by grinding of samples, was carried out before and after immersion in simulated body fluid (SBF) by powder X-ray diffraction analysis (XRD) (Vertex 70. Bruker, Hong Kong) and Fourier 
transformation infrared spectroscopy (FTIR) (JEOL JSM 5410, Japan). The surface morphological features of the scaffolds were examined by Scanning Electron Microscope (SEM) before and after immersion in SBF.

\section{Porosity measurement using mercury intrusion porosimetry (MIP):}

Mercury intrusion porosizer (Mercury intrusion poresizer, Model: 9320 V2.08, Micrometrices Inc., USA) was used to determine pore size distribution and percent porosity. ${ }^{(19)}$ Five samples were prepared for each group $(n=5)$ to be analyzed. The percent porosity was calculated according to the following equation: ${ }^{(19)}$

Where $=$ Sample's bulk density and $=$ Sample's apparent density.

\section{Mechanical testing:}

Compressive strength testing (sample size; $10 \times 10 \times 5 \mathrm{~mm})^{(16)}$ and indirect tensile strength testing (15 mm diameter x10 mm length) were conducted were conducted to assess the mechanical performance of scaffold deformation behavior. The tests were performed using a computer controlled universal testing machine (LRX plus, LC5KN, LIoyd Instrument Ltd, Fareham, UK) with a load cell of $5 \mathrm{kN}$ at cross-head speed of $0.5 \mathrm{~mm} / \mathrm{min}$. For each test, five values for each group were calculated and statistically analyzed.

\section{In vitro bioactivity test:}

\section{Assessment of bioactivity:}

Generally, $0.1 \mathrm{~g}$ scaffold was soaked for in a polyethylene bottle containing $20 \mathrm{~mL}$ of $\mathrm{SBF}$ at $37{ }^{\circ} \mathrm{C}$ for 1,3 and 7 days. The SBF was replaced every time. After each interval, the scaffolds were collected, washed with ethanol and de-ionized water, and dried at $37^{\circ} \mathrm{C}$ to be examined with SEM, FTIR and XRD analysis in order to evaluate the apatite forming ability at the surface of the scaffolds ${ }^{(20)}$.

\section{Assessment of biodegradability:}

The chemical composition of the SBF was analyzed with an inductively coupled plasma optical emission spectrometer (ICP-OES) to evaluate the changes in the concentrations of Silicon, Calcium, Phosphorus, Zinc, Zirconium and Strontium during the in vitro bioactivity test at the predetermined time intervals ${ }^{(14)}$.

\section{STATISTICAL ANALYSIS:}

The data of porosity, biodegradability, $\mathrm{PH}$ values and compressive and tensile strength values were tabulated. The porosity data were statistically analyzed using the one way analysis of variance (ANOVA) test. The compressive and tensile strength values were statistically analyzed using the one-way analysis of variance (ANOVA) and the least significant difference (LSD) tests. Also, the biodegradability data and the $\mathrm{PH}$ values were statistically analyzed by using the two-way analysis of variance (ANOVA) and LSD tests. A p-value $<0.05$ was considered statistically significant. Pearson's correlation was used to correlate between ICP-OES quantification of the ions released and the $\mathrm{PH}$ values.

\section{RESULTS}

\section{Characterization of bioglass samples}

\section{Thermal behavior of the glass systems} (Thermal analyses):

The mass loss detected in the TGA curve occurred in three different stages; In stage I, there was only $2 \%$ mass loss while in stage II and III, $9.83 \%$ and $50 \%$ mass loss occurred; respectively. As observed in the DTA curve, these stages were endothermic processes arises in the ranges of 100$200^{\circ} \mathrm{C}, 200-300^{\circ} \mathrm{C}$ and $300-600^{\circ} \mathrm{C}$; respectively. Above $700^{\circ} \mathrm{C}$, the mass loss became insignificant. On the DTA curve, a small deviation of the baseline corresponding to the glass transition temperature (Tg) was observed at approximately $700^{\circ} \mathrm{C}$. 
Also, other small oddly exothermic peaks of the crystallization temperatures (Tc) were detected at approximately $900^{\circ} \mathrm{C}$ (Figure 1).

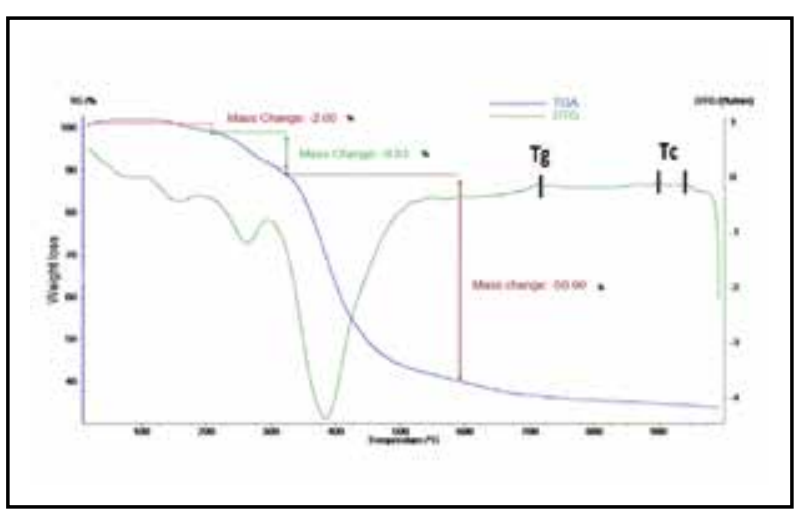

Fig. (1) Thermo-gravimetric analyses (TGA/DTA) of the scaffold samples after gelation showing the mass changes, glass transition temperature (Tg) and crystallization temperature $(\mathrm{Tc})$.

\section{X-Ray Diffraction (XRD) analysis:}

Before immersion in SBF, XRD patterns of BG, BG-Zn, BG-Zr and BG-Sr samples after calcination at $700^{\circ} \mathrm{C}$ were shown in Figure (2). XRD pattern of those four groups showed no diffraction peaks except a broad reflection at $2 \theta=15-35^{\circ}$.

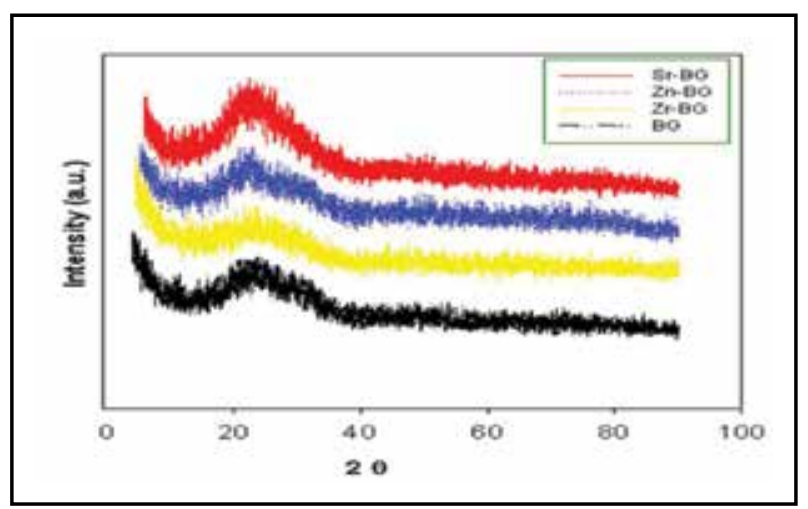

Fig. (2) X-ray diffraction Pattern of the tested bioglass groups showing the amorphous structure.

\section{Fourier Transformation infra-red (FTIR) analysis:}

The spectra of BG, Sr-BG, Zr-BG and ZnBG samples (Figure 3) after calcination at $700^{\circ} \mathrm{C}$ revealed the presence of stretching and bending vibration bands of both $\mathrm{Si}-\mathrm{O}-\mathrm{Si}$ and $\mathrm{P}-\mathrm{O}$ bonds in amorphous state. The shoulder of Si-O stretching vibration with one non-bridging oxygen (NBO) per $\mathrm{SiO}_{4}$ tetrahedron at about $952 \mathrm{~cm}^{-1}$ is more pronounced in the control BG and $\mathrm{Sr}-\mathrm{BG}$ groups and absent in $\mathrm{Zn}-\mathrm{BG}$ samples. Furthermore, the broadening of the band centered at $1067 \mathrm{~cm}^{-1}$ towards lower value was another important feature in the spectrum of Sr-BG group. FTIR spectra of Zr$\mathrm{BG}$ and $\mathrm{Zn}-\mathrm{BG}$ groups showed increase in intensity of the band at 1043 and $1067 \mathrm{~cm}^{-1}$ corresponding to stretching vibrations of $\mathrm{Si}-\mathrm{O}-\mathrm{Si}$ bond as well as reduction of stretching vibrations of Si-O-NBO band at $952 \mathrm{~cm}^{-1}$.

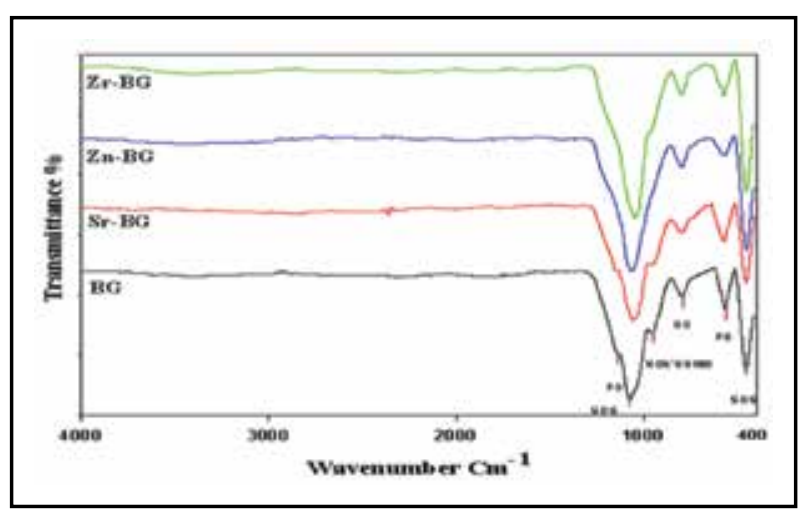

Fig. (3) FTIR spectra of control BG, Zr-BG, Zn-BG and Sr-BG samples from 4000 to $400 \mathrm{~cm}^{-1}$

\section{Scanning Electron Microscopic (SEM) examination}

SEM micrographs (Magnification x50) of the surface structure of all scaffolds demonstrated complex opened and interconnected hierarchical macroporous structure. The pore size ranges from 150 - $400 \mu \mathrm{m}$; (Figure 4). 


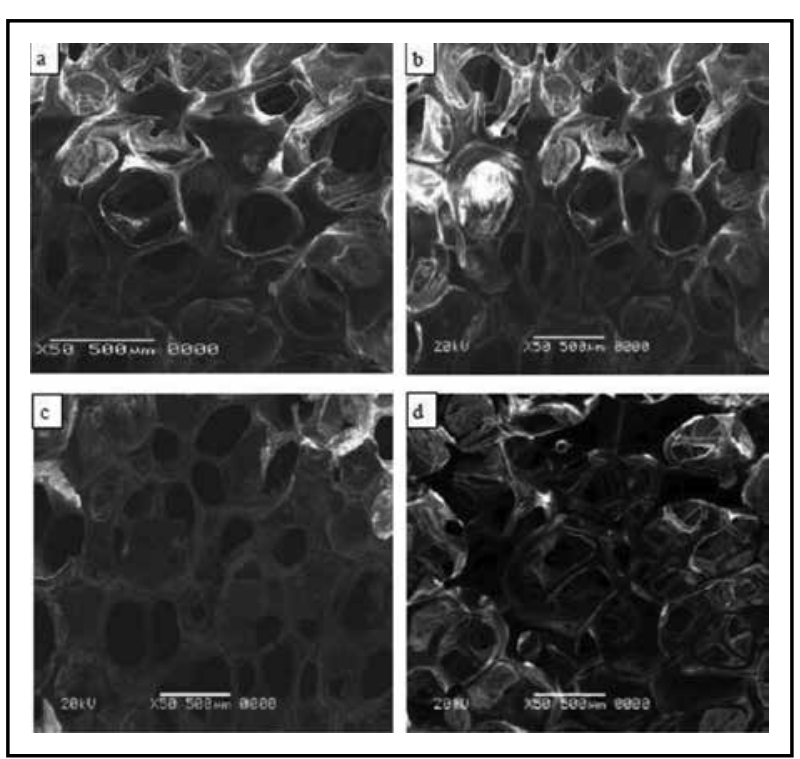

Fig. (4) SE micrographs of a) control BG, b) Sr-BG, c) Zr-BG d) Zn-BG at x50 showing interconnected porosity

\section{Porosity measurement using mercury intrusion porosimetry (MIP):}

The results of the bulk and apparent densities and percent porosities of all groups are shown in table (2). The results revealed insignificant differences between the groups. The porosity of the control BG, Sr-BG, Zr-BG and Zn-BG scaffolds was estimated at $83.08 \pm 3.48,82.14 \pm 6.11,81.2 \pm 3.83$ and 80.99 $\pm 6.99 \%$, respectively.

Table (2): The mean and standard deviation values of the bulk densities $(\mathrm{g} / \mathrm{mL})$, apparent densities $(\mathrm{g} / \mathrm{mL})$ and percent Porosity of the four bioglass groups.

\begin{tabular}{|c|c|c|c|}
\hline Group & Bulk density & $\begin{array}{c}\text { Apparent } \\
\text { density }\end{array}$ & $\begin{array}{c}\text { Percent } \\
\text { porosity }\end{array}$ \\
\hline BG & $0.293 \pm 0.054$ & $1.73 \pm 0.501$ & $83.082 \pm 3.482$ \\
\hline Sr-BG & $0.274 \pm 0.065$ & $1.534 \pm 0.881$ & $82.136 \pm 6.11$ \\
\hline Zr-BG & $0.250 \pm 0.062$ & $1.33 \pm 0.402$ & $81.204 \pm 3.827$ \\
\hline Zn-BG & $0.244 \pm 0.069$ & $1.271 \pm 0.978$ & $80.966 \pm 6.993$ \\
\hline $\begin{array}{c}\text { P } \\
\text { value }\end{array}$ & 0.5985 & 0.7944 & 0.9197 \\
\hline
\end{tabular}

\section{Mechanical testing:}

The means, standard deviations of compressive strength and tensile strength in MPa of the investigated bioglass samples are listed in Table (3). The control BG group showed the significantly highest compressive strength recording $0.051 \pm 0.002$ $\mathrm{MPa}(\sim 51 \mathrm{kPa})$. The control BG group showed the statistically significant highest mean compressive strength value followed by the $\mathrm{Zr}-\mathrm{BG}$ group and Zn-BG group. Meanwhile, the Sr-BG group exhibited the significantly lowest mean compressive strength value. The $\mathrm{Zn}-\mathrm{BG}$ and $\mathrm{Sr}-\mathrm{BG}$ groups exhibited significantly lower mean tensile strength values without statistically significant difference.

Table (3): The mean and standard deviation values of the compressive strength and indirect tensile strength in MPa of the tested bioglass samples:

\begin{tabular}{|c|c|c|c|}
\hline $\begin{array}{c}\text { Group } \\
\text { name }\end{array}$ & $\begin{array}{c}\text { Compressive } \\
\text { Strength } \\
\text { (MPa) }\end{array}$ & $\begin{array}{c}\text { Diametral } \\
\text { Tensile } \\
\text { Strength } \\
\text { (MPa) }\end{array}$ & \multirow{2}{*}{ P-value } \\
\hline BG & $0.051^{\mathrm{a}} \pm 0.002$ & $0.026^{\mathrm{a}} \pm 0.003$ & \\
\cline { 1 - 2 } Zr-BG & $0.04^{\mathrm{b}} \pm 0.007$ & $0.026^{\mathrm{a}} \pm 0.004$ & \multirow{2}{*}{0.0001} \\
\cline { 1 - 1 } Zn-BG & $0.031^{\mathrm{c}} \pm 0.001$ & $0.021^{\mathrm{b}} \pm 0.005$ & \\
\cline { 1 - 3 } Sr-BG & $0.024^{\mathrm{d}} \pm 0.004$ & $0.018^{\mathrm{b}} \pm 0.002$ & \\
\cline { 1 - 3 } & & &
\end{tabular}

* P-value <0.05 was considered statistically significant.

* Mean values of the same letters in the same column are insignificantly different

\section{In vitro bioactivity test:}

\section{Assessment of bioactivity:}

\section{X-Ray Diffraction (XRD) analysis:}

The XRD patterns of the four bioglass groups after immersion in SBF for 1, 3 and 7 days are shown in Figure (5). The peak values were compared with atomic planes (002), (211) and (112) corresponding to Hydroxyapatite (HA) according to the standard JCPDS file number (82 -1943). Other peak values 


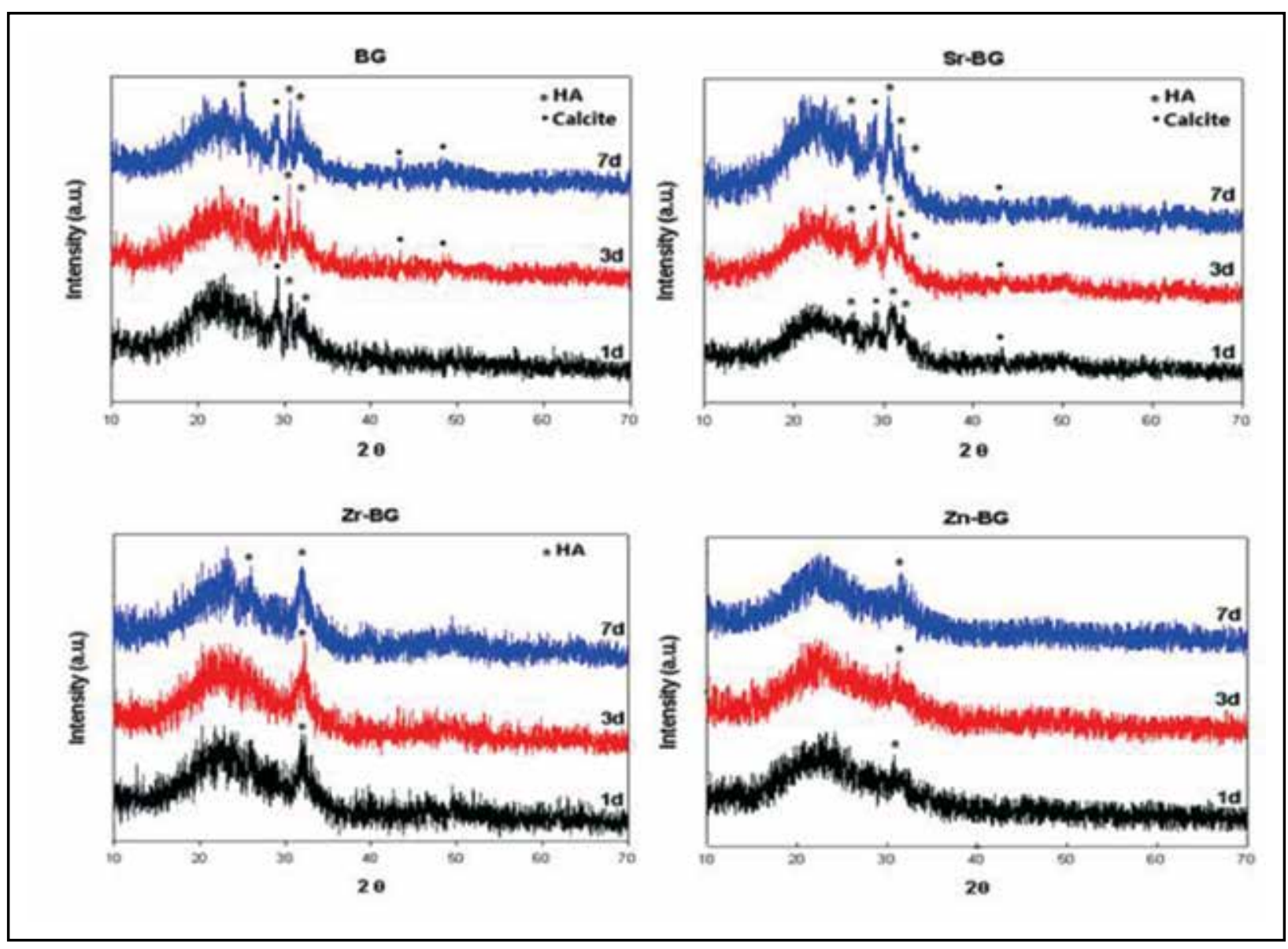

Fig. (5) X-ray diffraction Patterns of all groups at 1, 3\& 7 days

were compared with atomic planes (104), (202) and (116) corresponding to Calcite according to the standard JCPDS file number (01-081-2027).

The XRD patterns of the control (BG) samples revealed that the maximum peak relative $I_{/}$ intensity of $100 \%$ was found at $2 \theta=29.3^{\circ}$ for Calcite in the $1^{\text {st }}$ day; and then at $2 \theta=31^{\circ}$ for nanostructured $\mathrm{HA}$ in the $3^{\text {rd }}$ and $7^{\text {th }}$ days of immersion. Whereas for Sr-BG samples the maximum peak relative $\mathrm{I} / \mathrm{I}_{\mathrm{o}}$ intensity of $100 \%$ was found for nanostructured HA at $2 \theta=31^{\circ}$ and for calcite at $2 \theta=29.3^{\circ}$ in the $1^{\text {st }}$ day, $3^{\text {rd }}$ and $7^{\text {th }}$ days of immersion. For Zr-BG samples, the maximum peak relative $\mathrm{I} / \mathrm{I}_{\mathrm{o}}$ intensity of $100 \%$ was found for nanostructured $\mathrm{HA}$ at $2 \theta=32^{\circ}$ in the $1^{\text {st }}, 3^{\text {rd }}$ and $7^{\text {th }}$ days of immersion. However, only one weak peak was identified for nanostructured HA at $2 \theta=31^{\circ}$ in the $1^{\text {st }}, 3^{\text {rd }}$ and $7^{\text {th }}$ days of immersion for Zn-BG samples.
Fourier Transformation infra-red (FTIR) analysis:

The FTIR spectra of the of the investigated bioglass samples recorded at $1^{\text {st }}, 3^{\text {rd }}$ and $7^{\text {th }}$ day of immersion in transmittance mode in the spectral region 2000 to $400 \mathrm{~cm}^{-1}$ are shown in Figure (6).

\section{Scanning Electron Microscopic(SEM) examination:}

The change in surface morphology of the control, Sr-BG, Zr-BG and Zn-BG samples observed by SEM after dipping in SBF solution are shown in Figure (7) at magnification x1500.The control BG and $\mathrm{Sr}-\mathrm{BG}$ groups show large flake-like or equiaxed crystals that aggregate with the immersion time. Whereas, The Zr-BG and Zn-BG groups develop smaller equiaxed crystals that change to needle-like crystals in the $7^{\text {th }}$ day of immersion in the Zn-BG group. 


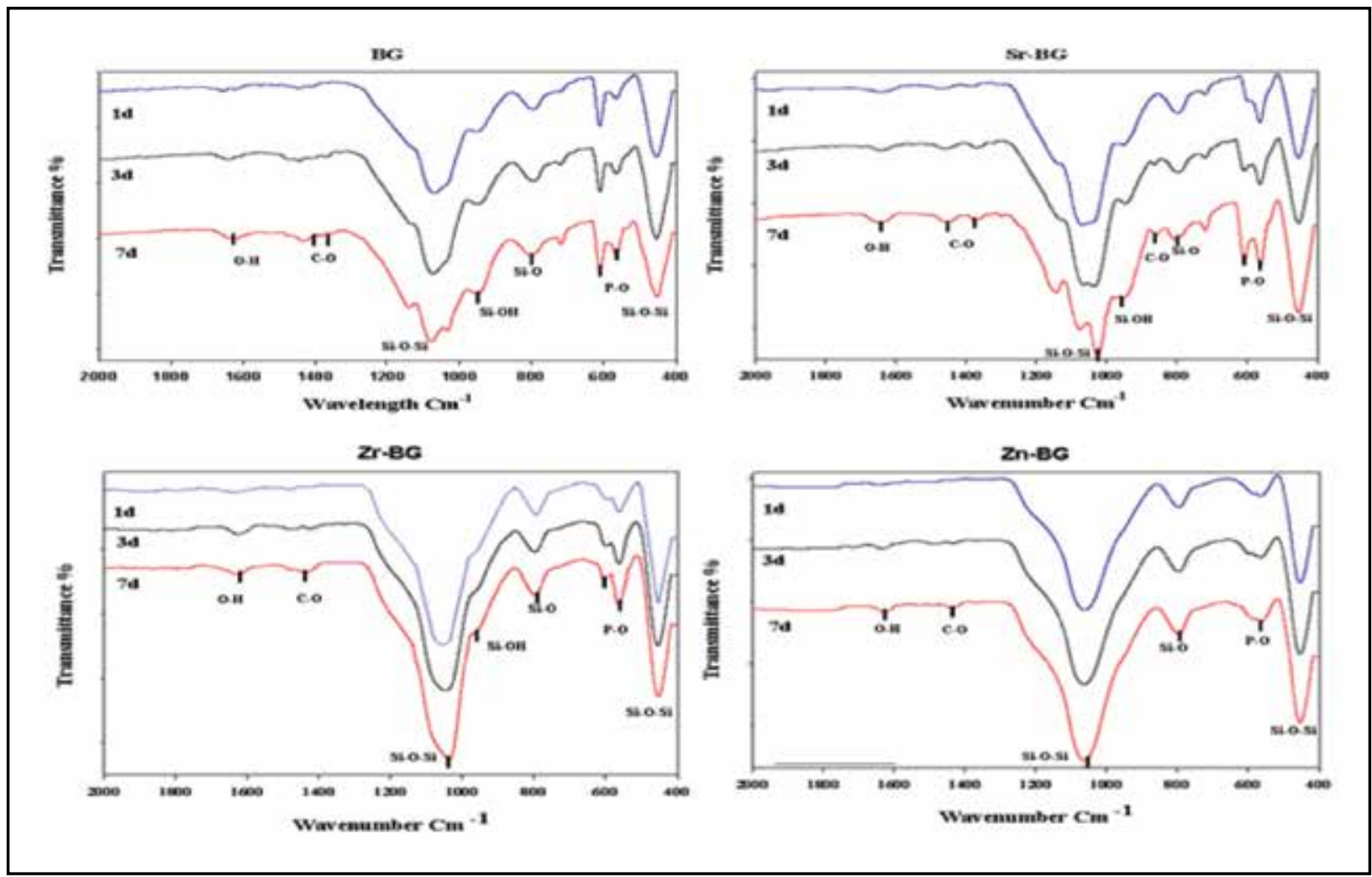

Fig. (6) FTIR spectra of the tested bioglass groups after immersion in SBF from 2000 to $400 \mathrm{~cm}^{-1}$

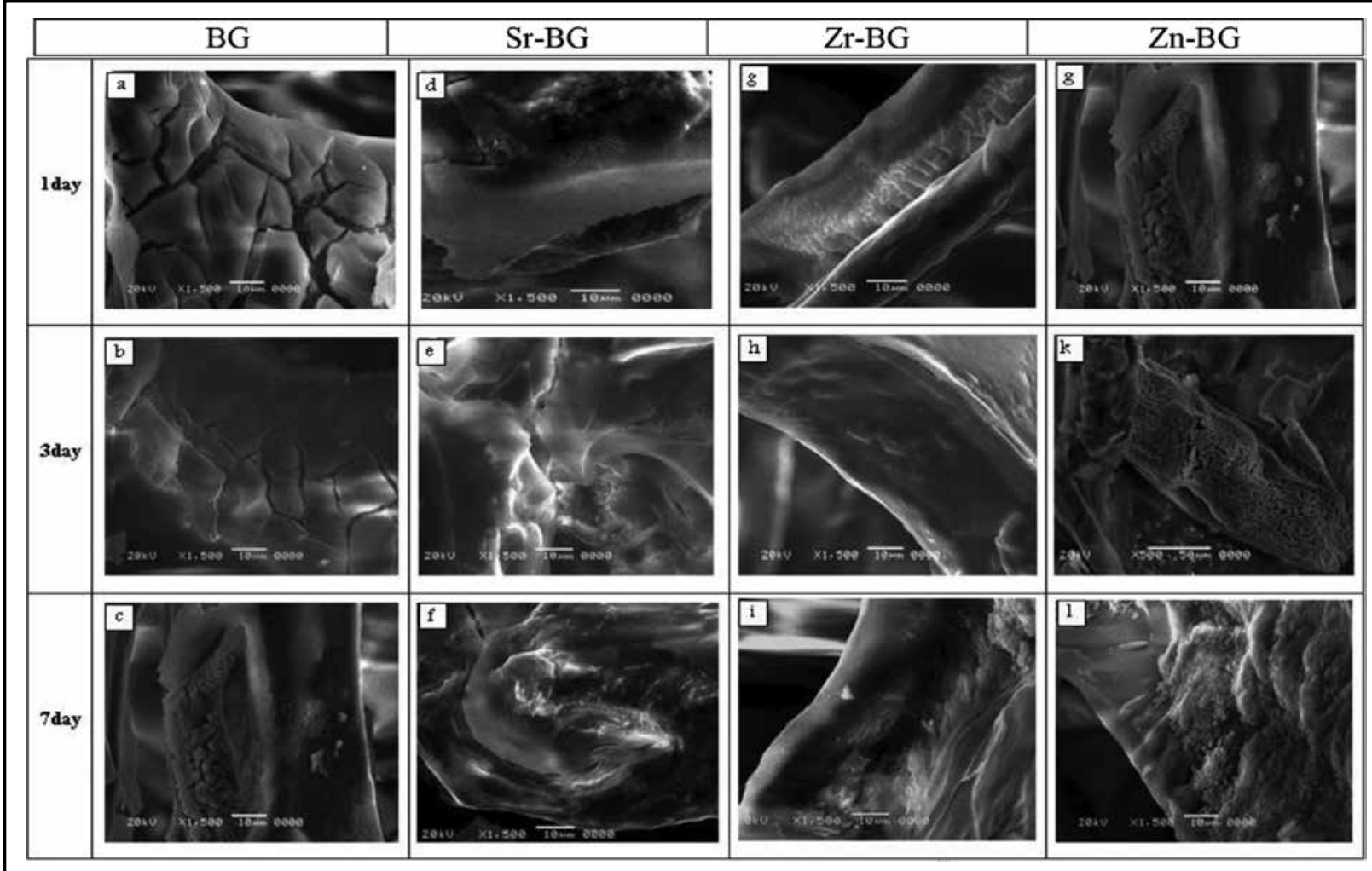

Fig. (7) SE micrographs (X1500) showing HA formation on BG, Sr-BG, Zr-B and Zn-BG after soaking in SBF for 1, 3 \&7 days 


\section{Assessment of biodegradability:}

The amount of released ions (ppm) from each of the synthesized groups at the predetermined time intervals are shown in Figure (8). The concentration of $\mathrm{Si}$ ions in SBF solutions of the $\mathrm{Sr}-\mathrm{BG}$ group exhibited the significantly highest values with the increase of soaking time at the $1^{\text {st }}$ day, whereas, $\mathrm{Zn}$ BG group showed the significantly lowest mean. Moreover, Si release from Sr-BG significantly increased by soaking time. The concentration of $\mathrm{Ca}$ ions in SBF solutions of the control BG, Sr-BG and $\mathrm{Zr}$-BG groups significantly decreased with the increase of soaking time. However, $\mathrm{Ca}^{2+}$ release from $\mathrm{Zn}$-BG scaffolds significantly increased by time. $\mathrm{Ca}^{2+}$ release from $\mathrm{Zr}$-BG group exhibited the significantly highest mean at the $1^{\text {st }}$ day. The concentration of $\mathrm{P}$ ions in SBF solutions of all groups significantly decreased with the increase of soaking time. The $\mathrm{PH}$ values recorded for each group at the predetermined time intervals are shown in Figure (9). The PH values for the four groups the four groups significantly increased by soaking time. Sr-BG recorded the significantly highest $\mathrm{PH}$ value, while $\mathrm{Zn}$-BG scaffolds reported the significantly lowest $\mathrm{PH}$ value.

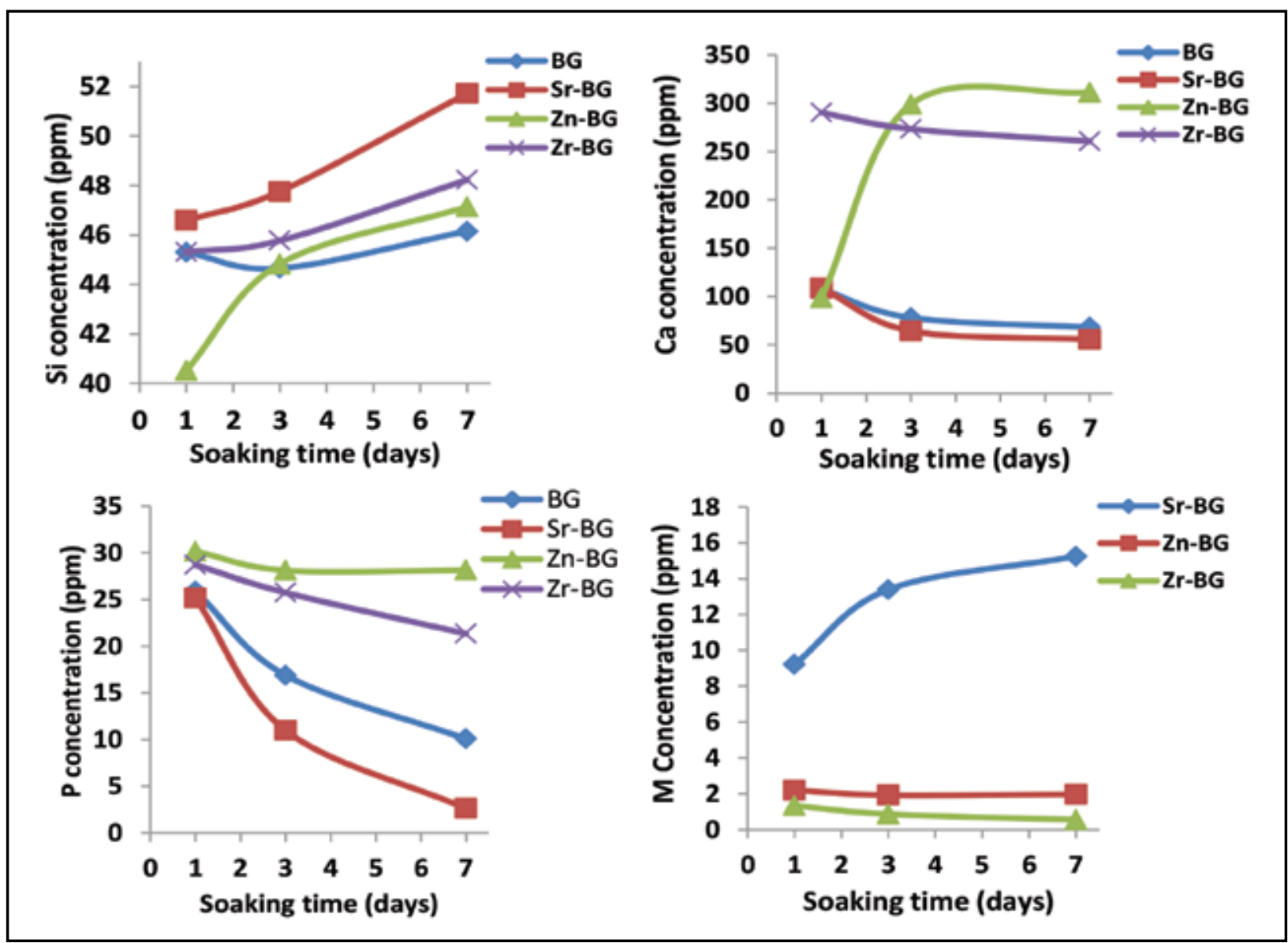

Fig. (8) The released amount of Si, Ca, P, Sr, Zr and $\mathrm{Zn}$ (ppm) from Sr-BG, Zr-BG and Zn-BG samples at the predetermined time intervals 


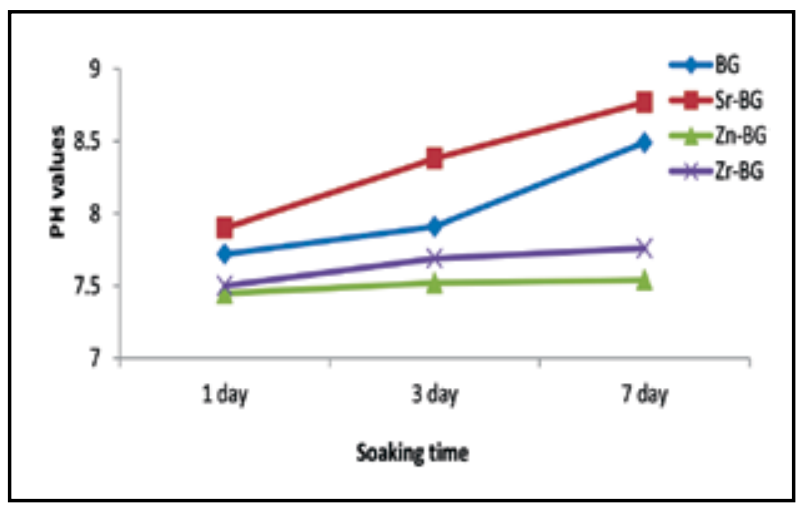

Fig. (1) The PH values of control BG, Sr-BG, Zr-BG and Zn$\mathrm{BG}$ samples at the predetermined time intervals

\section{DISCUSSION}

In the present study, the sol-gel method was used to prepare the bioglass system owing to the high nanoporosity and surface area of the prepared bioglass that improve its reactivity/solubility and the cellular response. ${ }^{(21,22)}$

\section{Characterization of bioglass samples:}

Thermal behavior of the glass systems (Thermal analyses):

The thermo-gravimetric analyses instrument (TGA) and differential thermal analysis (DTA) was carried out to estimate the exact sintering temperature. The mass loss observed in the TGA curve occurred in three distinct stages corresponding to endothermic processes on DTA curve as shown in Figure(1). The first mass loss occurred in the range of $100-200^{\circ} \mathrm{C}$ is attributed to the loss of physically adsorbed water and ethanol evaporation.In stage II, the mass loss corresponds to the elimination of chemically adsorbed water occurred in the range of $200-300^{\circ} \mathrm{C}$. The final mass loss, in the $300-600$ ${ }^{\circ} \mathrm{C}$ temperature range accounted to condensation of silanol groups and elimination of the remaining nitrates of the precursors and organic compounds of the co-templates ${ }^{(22,23)}$.

According to the obtained results, the calcination temperature was established at $700{ }^{\circ} \mathrm{C}$ for all the samples. A small deviation of the baseline of the curves was observed at approximately 700 ${ }^{\circ} \mathrm{C}$, characterizing the range of glass transition temperature $\mathrm{Tg}$ for each glass system. The exothermic events observed at approximately $900^{\circ} \mathrm{C}$ are associated with the crystallization temperature (Tc) for each glass system. The crystallization temperatures Tc of the glass systems were easily observed by DTA at approximately $900^{\circ} \mathrm{C}$. The results of the present study were consistent with a previous study that reported $700{ }^{\circ} \mathrm{C}$ as stabilization temperature for the same glass system $\left(80 \mathrm{SiO}_{2}-\right.$ $\left.15 \mathrm{CaO}-5 \mathrm{P}_{2} \mathrm{O}_{5}\right)^{(15)}$.

\section{X-Ray Diffraction (XRD) analysis:}

The presence of broad reflection at $2 \theta=15$ $35^{\circ}$ (Figure 2) denotes a wide $\mathrm{SiO}_{2}$ peak with low intensity which indicates the amorphous nature of all the synthesized glass groups. Therefore, the partial substitution of $\mathrm{ZrO}_{2}, \mathrm{ZnO}$ or $\mathrm{SrO}$ for $\mathrm{SiO}_{2}$ did not change the phase structure of the synthesized scaffolds. This result was in agreement with that of other researchers who prepared amorphous bioglass using the same bioglass composition that was sintered at $700^{\circ} \mathrm{C}^{(24)}$.

\section{Fourier Transformation infra-red (FTIR) analysis:}

The presence of stretching and bending vibration bands of both $\mathrm{Si}-\mathrm{O}-\mathrm{Si}$ and $\mathrm{P}-\mathrm{O}$ bonds in amorphous state (Figure 3) confirmed the main functional groups of the bioglass system ${ }^{(15,21)}$. The shoulder of Si-O stretching vibration with one non-bridging oxygen (NBO) per $\mathrm{SiO}_{4}$ tetrahedron at about $952 \mathrm{~cm}^{-1(25)}$ is more pronounced in the control $\mathrm{BG}$ and $\mathrm{Sr}-\mathrm{BG}$ groups and absent in $\mathrm{Zn}-\mathrm{BG}$ samples. Furthermore, the broadening of the band centered at $1067 \mathrm{~cm}^{-1}$ towards lower value was another important feature in the spectrum of Sr-BG group. The authors attributed this result to $\mathrm{O}-\mathrm{Si}-\mathrm{O}$ stretching vibrations with two NBO, specific for silicate matrices with high modifier content ${ }^{(26)}$. These characteristic changes is related to the behavior of strontium as a glass network modifier. When a network modifier 
$\left(\mathrm{Ca}^{2+}\right.$ and $\left.\mathrm{Sr}^{2+}\right)$ is added to the glass system a number of Si-O-Si and P-O-P bonds are broken. The added oxygen saturates the unsatisfied bond of one $\mathrm{Si}$ and two Si-O bonds are created ${ }^{(27)}$. The presence of nonbridging oxygens lowers the relative number of strong bonds and disrupts the network. On the other hand, FTIR spectra of Zr-BG and Zn-BG groups showed increase in intensity of the band at 1043 and $1067 \mathrm{~cm}^{-1}$ corresponding to stretching vibrations of $\mathrm{Si}-\mathrm{O}-\mathrm{Si}$ bond as well as reduction of stretching vibrations of Si-O-NBO band at $952 \mathrm{~cm}^{-1}$. This may be attributed to the behavior of zirconium and zinc oxides in replacement of $\mathrm{SiO}_{2}$ as intermediate elements that can function either as modifiers or as network formers ${ }^{(16,28)}$. Zinc and zirconium ions can also form tetrahedral $\mathrm{ZnO}_{4}^{2-}$ species which require $\mathrm{Ca}$ ions for charge balancing. This removes cations from the silica network and increase numbers of bridging oxygen. The newly formed $\mathrm{Si}-\mathrm{O}-\mathrm{Zn}$ and $\mathrm{Si}-\mathrm{O}-\mathrm{Zr}$ bonds have significantly lower bond strength than $\mathrm{Si}-\mathrm{O}-\mathrm{Si}$ bonds in the silicate chain.

\section{Scanning Electron Microscopic (SEM) examination:}

SEM micrographs (Figure 4) of the surface structure of all scaffolds demonstrated complex hierarchical structure of rough struts and mostly opened interconnected macropores(150 - $400 \mu \mathrm{m})$, a value which satisfies the requirements to allow cell infiltration and new vascularization ${ }^{(29,30)}$. It was suggested that the partial substitution of $\mathrm{ZrO}_{2}, \mathrm{ZnO}$ or $\mathrm{SrO}$ for $\mathrm{SiO}_{2}$ did not change the macroporous structure of the scaffolds. Moreover, the rough surface of the struts is expected to help cell adhesion after implantation ${ }^{(31)}$. The results of the current study are in agreement with previous study ${ }^{(24)}$ that prepared $\mathrm{CaO}-\mathrm{M}_{\mathrm{x}} \mathrm{O}_{\mathrm{y}}-\mathrm{SiO}_{2}-\mathrm{P}_{2} \mathrm{O}_{5}(\mathrm{M}=\mathrm{Zr}, \mathrm{Mg}, \mathrm{Sr})$ scaffolds that demonstrated interconnected macroporous structures with comparable pore size; ranging from 200 to $400 \mu \mathrm{m}$ with smooth surface pore walls. Another study prepared Sr-MBG scaffolds by the typical polymer sponge method and showed similar porous structure with pore size ranging roughly from 300 to $500 \mu \mathrm{m}$ compared to the present study
(150- $400 \mu \mathrm{m})$. This isprobably due to different criteria of PU foam having $20 \mathrm{ppi}^{(32)}$.

\section{Porosity measurement using mercury intrusion porosimetry (MIP):}

The results of the bulk and apparent densities and percent porosities of all groups revealed insignificant differences between the groups. The porosity of the control BG, Sr-BG, Zr-BG and Zn-BG scaffolds was estimated at $83.08 \pm 3.48,82.14 \pm 6.11,81.2$ \pm 3.83 and $80.99 \pm 6.99 \%$, respectively. Therefore, the partial substitution of $\mathrm{ZrO}_{2}, \mathrm{ZnO}$ or $\mathrm{SrO}$ for $\mathrm{SiO}_{2}$ did not change the percent porosity of the scaffolds. The prepared $\mathrm{CaO}-\mathrm{M}_{\mathrm{x}} \mathrm{O}_{\mathrm{y}}-\mathrm{SiO}_{2}-\mathrm{P}_{2} \mathrm{O}_{5}(\mathrm{M}=\mathrm{Zr}$ and $\mathrm{Sr}$ ) scaffolds; despite of having comparable pore size, they recorded $88.6,87.9$ and $86.8 \%$ porosity for the control, $\mathrm{Zr}$-containing and $\mathrm{Sr}$-containing scaffolds; respectively ${ }^{(24)}$. These higher values may be due to using different measuring technique.

\section{Mechanical testing:}

The estimation of the scaffold's mechanical Properties is essential to govern its potential clinical applications. The control BG group showed the significantly highest compressive strength recording $0.051 \pm 0.002 \mathrm{MPa}(\sim 51 \mathrm{kPa})$. This result is approved in other studies that showed close compressive strength value of the $\mathrm{CaO}-\mathrm{SiO}_{2}-\mathrm{P}_{2} \mathrm{O}_{5}$ bioactive glass scaffold $(53 \mathrm{kPa})$, and also higher than HAp scaffold (30 $\mathrm{kPa})$ and b-TCP scaffold $(50 \mathrm{kPa})^{(16,24)}$.

The Zr-BG group estimated compressive strength of $0.04 \pm 0.007 \mathrm{MPa}(\sim 40 \mathrm{kPa})$ higher than that of Zn-BG and Sr-BG groups. This could be explained by the fact that zirconium ions $\left(\mathrm{Zr}^{4+}\right)$ can form a tetrahedron network with $\mathrm{O}$ ions replacing $\mathrm{Si}^{4+}$ ions, which is more stable than $\mathrm{Sr}$ or $\mathrm{Zn}$ ions that form ionic bonding to $\mathrm{Si}$ and $\mathrm{O}$ network. This confirms the FTIR results; that $\mathrm{Zr}$ ions act as network former in the bioglass system. Although zirconium and silicon ions are considered glass formers, the substitution of $\mathrm{ZrO}_{2}$ for $\mathrm{SiO}_{2}$ reduced the compressive strength of the $\mathrm{CaO}-\mathrm{SiO}_{2}-\mathrm{P}_{2} \mathrm{O}_{5}$ 
bioglass system more than the control. Moreover, further reduction of the compressive strength of bioglass system was induced by the substitution of $\mathrm{ZnO}$ for $\mathrm{SiO}_{2}$. This decline could be due to the lower ionic field strength $(\mathrm{Z} / \mathrm{r})$ of $\mathrm{Zn}^{2+}$ and $\mathrm{Zr}^{4+}$ than that of $\mathrm{Si}^{4+}$, recording $0.015,0.025$ and $0.034 \AA^{-1}$, respectively. The ionic field strength $(I=Z / r)$ is defined as charge over radius $(Z / r)^{(33)}$.

Stronium oxide $(\mathrm{SrO})$ is considered network modifier in the glass system as proved by FTIR analysis. Therefore, in contrast to $\mathrm{SiO}_{2}$ or $\mathrm{P}_{2} \mathrm{O}_{5}$ (network formers), after addition to glass system, this oxide will break the chains of $\mathrm{SiO}_{4}$ and $\mathrm{PO}_{4}$, interrupting the bonds of bridging oxygens (Si$\mathrm{O}-\mathrm{Si}$ and $\mathrm{P}-\mathrm{O}-\mathrm{P}$ ) and generating more non-bridging oxygens at the ends of the chains ${ }^{(18)}$. For this reason, the Sr-BG group displayed the significantly lowest compressive strength value; recording $0.024 \pm 0.004$ $\mathrm{MPa}(\sim 24 \mathrm{kPa})$. These results are in disagreement with another study that reported higher strength values of $\mathrm{ZrO}_{2}$ and SrO- substituted bioglass scaffolds of the same composition that may be attributed to the fact that $\mathrm{Zr}$ and $\mathrm{Sr}$ oxides replace $\mathrm{CaO}$ in the bioglass system ${ }^{(16,24)}$.

\section{In vitro bioactivity test:}

\section{Assessment of bioactivity:}

\section{X-Ray Diffraction (XRD) analysis:}

After soaking the samples of the synthesized groups in SBF solution for seven days, certain peaks appeared in the XRD patterns (Figure 5), indicating the formation of the crystalline HA layer on the surface of all bioglass samples. This indicates that the synthesized groups are bioactive and might be suitable to support bone cell and tissue growth. The gradual growth in the intensity of the individual reflections, the appearance of other low intensity apatite reflections and the narrowing of the peak width clearly illustrated the growth of the crystalline HA surface layer as a function of immersion time in SBF. The wide diffraction peak

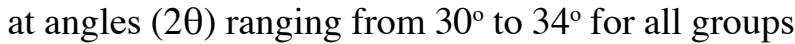
corresponds to the overlapping of (112) and (300) reflections of the well-crystallized $\mathrm{HA}^{(34)}$ or due to the microcrystalline nature of apatite precipitates ${ }^{(31)}$.

Furthermore, the higher apatite-forming ability of the Sr-BG and control BG groups may be attributed to the high network modifier content ( $\mathrm{SrO}$ and $\mathrm{CaO}$ ) specially in $\mathrm{Sr}-\mathrm{BG}$ group as demonstrated by FTIR analysis before samples' immersion in SBF. At the same time intervals, the diffraction intensities of most atomic planes of apatite phase formed on Sr-BG group are higher than that formed on the control group (Figure 5). These results can approve the accelerating effect of $\mathrm{Sr}$ ions on apatite formation ability of the bioglass system which is in agreement with previous studies reported for other systems $^{(35,36)}$.

On the other hand, $\mathrm{ZrO}_{2}$ substitution lead to moderate bioactivity that was revealed on the appearance of only one HA peak at $2 \theta=32^{\circ}$ at different intervals; exceeded by another HA peak at $2 \theta=25.98^{\circ}$ at the $7^{\text {th }}$ day of immersion (Figure 5). Both Zr-BG and Zn-BG groups showed decreased number of diffraction peaks that could be explained by the fact that zirconium and zinc increased the number of bridging oxygen in the bioglass system thus limiting its bioactivity. $\mathrm{ZnO}$ substitution showed the least degree of bioactivity among the four groups by exhibiting one HA peak $\left(2 \theta=32^{\circ}\right)$ in the XRD pattern at every time interval (Figure 5). This result is in disagreement with other study ${ }^{(37)}$ that revealed no change in XRD pattern of $\mathrm{Zn}$ containing $\mathrm{SiO}_{2}-\mathrm{CaO}$ bioglass system(5 mol\%) even after soaking in SBF for 31 days concluding that the $\mathrm{Zn}$ ions strongly inhibit the formation of apatite layer on the glass surface.

Strong reflections corresponding to calcite crystals are also observed in the XRD patterns of the control (BG) and Sr-BG samples immersed in $\mathrm{SBF}$ at all intervals. The presence of calcite crystals may be attributed to the reaction between calcium ion released from bioglass and carbonate ion in SBF 
solution. It has been reported that calcite as a form of calcium carbonate, is able to bond onto bone even without the formation of apatite layer ${ }^{(38)}$.

\section{Fourier Transformation infra-red (FTIR) analysis:}

After soaking the samples for 1 day in SBF, the band appeared at $563 \mathrm{~cm}^{-1}$ that is assigned to amorphous phosphate before soaking; had changed into a clear doublet (Figure 9) at about 563 and $601 \mathrm{~cm}^{-1}$, which is usually assigned to crystalline calcium phosphate (i.e. the main peaks for HA) ${ }^{(39)}$. By time, the doublet formation started at first day in Sr-BG, control BG and Zr-BG groups becomes more sharp and increasingly separated, or split, as crystallinity increases ${ }^{(40)}$. However, in the $\mathrm{Zn}$ BG samples the doublet was very weak at all time intervals, indicating a low in vitro bioactive response in these samples. These results are confirmed by the results obtained by XRD analysis.

The overlapping of $\mathrm{Si}-\mathrm{OH}$ and $\mathrm{Si}-\mathrm{O}$ with non-bridging oxygen (NBO)stretching vibrations observed at $950 \mathrm{~cm}^{-1}$ in all groups except Zn-BG group was more pronounced in the control $\mathrm{BG}$ and Sr-BG groups, indicating that the higher modifier content $(\mathrm{CaO}$ and $\mathrm{SrO})$ has disrupted the silicate network. The presence of NBO is known to promote glass leaching which is considered beneficial in promoting apatite formation, thus enhancing bioactivity ${ }^{(41)}$. The band located at $870 \mathrm{~cm}^{-1}$ in Sr-BG group and the large bands at 1470, 1420 and 1390 $\mathrm{cm}^{-1}$ in all groups can be assigned to $\mathrm{C}-\mathrm{O}$ vibration modes. These bands signify the incorporation of carbonate anions from the SBF in the apatite crystal lattice $^{(42)}$.

In the current study, the formation of crystalline phosphate layer on Sr-BG was observed after soaking in SBF for 1 day. This finding is in disagreement with a study ${ }^{(36)}$ that revealed the formation of the crystalline phosphate layer on $\mathrm{SiO}_{2}-\mathrm{CaO}$ bioglass system after 7 days of immersion. However, the results of FTIR spectra of Zn-BG are in accordance with that study that showed no considerable changes in FTIR spectra of Zn-containing bioglass before and after soaking in SBF.

\section{Scanning Electron Microscopic(SEM) examination:}

Confirming the XRD and FTIR results, SEM examination (Figure7) shows surface changes in the tested bioglass samples after soaking in SBF. The surface morphology changed completely after 1 day, with a layer of flake-like crystallites that increases the roughness of the surfaces. These crystallites are characteristics of the grown apatite on the glass surface. HA morphology can vary from acicular to equi-axed crystals and it depends on the concentration of carbonate $\operatorname{ion}\left(\mathrm{CO}_{3}{ }^{2-}\right)^{(43)}$. Therefore, the control BG and $\mathrm{Sr}-\mathrm{BG}$ groups show large flake-like or equiaxed crystals that aggregate with the immersion time. Whereas, The Zr-BG and Zn-BG groups develop smaller equiaxed crystals that change to needle-like crystals in the $7^{\text {th }}$ day of immersion in the Zn-BG group. These confirm the increased activity of the former groups and the decreased activity of the later.

\section{Assessment of biodegradability:}

The changes in the SBF composition during in vitro bioactivity and biodegradability tests can be used as an indirect method to realize the processes that are taking place in the glass surface. If the glass is partially soluble, a general requisite for bioactivity, an initial increase in $\mathrm{Ca}, \mathrm{P}$ and $\mathrm{Si}$ ions in solution would take place. Later on, $\mathrm{Ca}$ and $\mathrm{P}$ in solution would decrease if the calcium phosphate layer; as indicative of in vitro bioactivity, is formed ${ }^{(15)}$.

As displayed in Figure (8), with the increase of soaking time, Sr-BG scaffolds exhibited the significantly highest values of $\mathrm{Si}$ ion release. This could be attributed to its highest modifier content $\left(\mathrm{Ca}^{2+}\right.$ and in $\left.\mathrm{Sr}^{2+}\right)$. The highest $\mathrm{PH}$ value of this group attacks the silica network leading to more dissolution of Si ions as shown in Figure (9). Zn-BG scaffolds reported the significantly lowest $\mathrm{PH}$ value and hence $\mathrm{Si}$ ions release that is highly related to the lowest bioactivity of that group. However, the control 
group and Zr-BG group showed insignificantly increased Si ions release more than Zr-BG scaffolds indicating the increase in degradation rate of the scaffolds by time. All these findings indicate that Sr-BG scaffolds have the highest degradation rate followed by $\mathrm{Zr}-\mathrm{BG}$, whereas the control group and Zn-BG scaffold exhibited the lowest degradation rate.

The concentration of $\mathrm{Ca}$ ions in SBF solutions of the control BG, Sr-BG and Zr-BG groups (Figure 8)significantly decreased with the increase of soaking time, which might be attributed to the active precipitation process; where $\mathrm{Ca}$ ions share in the formation of hydroxyapatite (HA) layer on the scaffolds' surfaces as proved by the results of XRD, FTIR and SEM. Concurrently, $\mathrm{Ca}^{2+}$ release from $\mathrm{Zn}$-BG scaffolds significantly increased by time indicating that zinc cation that was replaced for $\mathrm{Si}$ in the bioglass system, diminished the calcium contribution for the apatite formation. Furthermore, $\mathrm{Ca}^{2+}$ release from $\mathrm{Zr}-\mathrm{BG}$ group exhibited the significantly highest mean at the $1^{\text {st }}$ day that could be interpreted by delayed bioactivity of that group in relation to $\mathrm{Sr}-\mathrm{BG}$ and the control BG. This finding is evidenced by FTIR analysis at the $1^{\text {st }}$ day of soaking; (Figure 6). Nevertheless, the mean values of $\mathrm{Ca}^{2+}$ release at the $3^{\text {rd }}$ and $7^{\text {th }}$ days significantly decreased in the following order; $\mathrm{Zn}-\mathrm{BG}<\mathrm{Zr}-\mathrm{BG}$ $<$ control BG $<$ Sr-BG signifying optimum HA formation in the same order.

The concentration of $\mathrm{P}$ ions in SBF solutions of all groups significantly decreased with the increase of soaking time due to its involvement in HA formation. The reduction in $\mathrm{P}$ ions concentration proceeds in the following order; $\mathrm{Zn}-\mathrm{BG}, \mathrm{Zr}$ BG, control BG and Sr-BG. This indicates the enhanced bioactivity in the following order; $\mathrm{Sr}$ $\mathrm{BG}$, control BG, Zr-BG and Zn-BG. These results were supported by the results of XRD, FTIR and SEM. As shown in Figure (8), the dissolution rate of $\mathrm{Sr}$ ions from the Sr-BG scaffold recorded the significantly highest values at the predetermined time intervals, while $\mathrm{Zr}$ and $\mathrm{Zn}$ ions release from their corresponding groups were extremely low. These results could be explained by the type of bond and the contribution of these ions in the bioglass network as indicated previously in FTIR analysis. Therefore, the substitution of $\mathrm{ZrO}_{2}, \mathrm{ZnO}$ or $\mathrm{SrO}$ for $\mathrm{SiO}_{2}$ resulted in the different dissolution rates of the ions from their corresponding groups, which caused the $\mathrm{pH}$ changes of the SBF solutions. As shown in Figure (9), the $\mathrm{pH}$ values of the control BG and SrBG scaffolds soaked in SBF solutions were close to 8.5 and 8.8 ; respectively after 7 days soaking. However, the $\mathrm{pH}$ value of the $\mathrm{Zr}-\mathrm{BG}$ and $\mathrm{Zn}-\mathrm{BG}$ scaffolds soaked SBF solution were only 7.8 and 7.5; respectively after 7 days soaking. This indicates that the substitution of $\mathrm{ZrO}_{2}$ and $\mathrm{ZnO}$ for $\mathrm{SiO}_{2}$ in the $\mathrm{CaO}-\mathrm{SiO}_{2}-\mathrm{P}_{2} \mathrm{O}_{5}$ bioglass scaffolds generally led to a slow dissolution rate of $\mathrm{Si}$ and $\mathrm{P}$ ions, and rapid dissolution of $\mathrm{Ca}$ ions while exhibiting significantly lower $\mathrm{pH}$ value in the surrounding environment, which is more desirable for cell adhesion and growth on the scaffolds. Moreover, the low PH value of $\mathrm{Zn}$ BG group may be attributed to ${ }^{(44)}$ formation of zinc hydroxide in the SBF solution.

The result of the current study is consistent with a previous study that reported the samples that contain the highest amount of zinc shows a slower dissolution process than the others. It is explained on the basis of the role of $\mathrm{ZnO}$ as network modifier and network former depending on the composition and its content ${ }^{(45)}$.

\section{CONCLUSIONS}

Within the limitations of this study, the following could be concluded:

1. Combination of sol-gel and foam replication methods were successfully used to prepare highly interconnected hierarchical macroporous bioglass scaffolds having more than $80 \%$ porosity.

2. The partial substitution of $\mathrm{ZrO} 2, \mathrm{ZnO}$ or $\mathrm{SrO}$ for $\mathrm{SiO} 2$ did not change the amorphous structure of the synthesized scaffolds. 
3. Strontium and zirconium ions in the bioglass system provoked a nanostructured Hydroxycarbonate apatite HCA layer formation, whereas $\mathrm{Zn}$ ions diminished the bioactivity.

4. Strontium ion substitution showed the highest biodegradability of the bioglass system.

5. Incorporation of $5 \mathrm{~mol} \%$ of $\mathrm{ZrO} 2, \mathrm{ZnO}$ or $\mathrm{SrO}$ in the sol-gel derived $\mathrm{SiO} 2-\mathrm{CaO}-\mathrm{P} 2 \mathrm{O} 5$

6. bioglass decreased the mechanical properties.

\section{REFERENCES}

1. Jones J R, Ehrenfried L M, Hench LL.Optimising bioactive glass scaffolds for bone tissue engineering. J Biomaterials. 2006; 27 : 964-73.

2. Wu C T, Zhang Y F, Zhu Y F, Friis T, Xiao Y.Structureproperty relationships of silk-modified mesoporousbioglass scaffolds. J Biomaterials. 2010; 31: 3429-38.

3. Ali S, Farooq I, Iqbal K. A review of the effect of various ions on the properties and the clinical applications of novel bioactive glasses in medicine and dentistry. Saudi Dental Journal. 2014; 26: 1-5.

4. Kokubo T, Takadama H. How useful is SBF in predicting in vivo bone bioactivity? Biomaterials. 2006; 27: 2907-15.

5. Hench LL. The story of Bioglass. J Mater Sci-Mater Med 2006; 11: 967- 78 .

6. Killion J A, Kehoe S, Geever L M, Devine D M, Sheehan E, and Boyd D. Hydrogel/ bioactive glass composites for bone regeneration applications: Synthesis and characterization. J Materials Sci and Eng.2013; 33: 4203-12.

7. Henstock J R, Canham L T, Anderson S I.Silicon: the evolution of its use in biomaterials.ActaBiomater. 2015; 11: 17-26.

8. Regi MV, Bala F. Silica material for biomedical applications. Open Biomed Eng J. 2008; 2: 1-9.

9. Cai S, Xu GH, Yu XZ, Zhang WJ, Xiao ZY, Yao KD. Fabrication and biological characteristics of b-tricalcium phosphate porous ceramic scaffolds reinforced with calcium phosphate glass. J Mater Sci Mater Med. 2009; 20: $351-8$.

10. Wu C, Zhou Y, Xu M, Han P, Lei C, Jiang C, Yin X. Copper-containing mesoporous bioactive glass scaffolds with multifunctional properties of angiogenesis capacity, osteostimulation and antibacterial activity. Biomaterials. 2013; 34: 422- 33 .
11. Xing M, Huan Z, Li Q, Yu J, Chang J.Containerless processing of $\mathrm{Ca}-\mathrm{Sr}-\mathrm{Si}$ system bioactive materials: thermophysical properties and ion release behaviors. Ceramics International. 2017;

12. Deliormanlı A M.Electrospun cerium and galliumcontaining silicate based 13-93 bioactive glass fibers for biomedical applications Ceramic international. 2016; 42: 897-906.

13. FarzinA, Fathi M H, Emadi R. Multifunctional magnetic nanostructured hardystonite scaffold for hyperthermia, drug delivery and tissue engineering applications. Materials Science and Engineering. 2017; 70: 21-31.

14. Shruti S, Antonio J S, Gigliola L, Gianluca M, Ledi M, Vallet-Regi M. Mesoporous bioactive scaffolds prepared with cerium-, gallium- and zinc-containing glasses. ActaBiomaterialia. 2013; 13: 4836-44.

15. Salinas A J, Shruti S, Malavasi G, Menabue L, Vallet-Reg M.Substitutions of cerium, gallium and zinc in ordered mesoporous bioactive glasses. ActaBiomaterialia. 2011; 7: 3452-8.

16. Zhu Y, Zhang Y, Wu C, Fang Y, Yang J, Wang S. The effect of zirconium incorporation on the physiochemical and biological properties of mesoporous bioactive glasses scaffolds. Microporous and Mesoporous Materials. 2011; 143: 311-19.

17. Kokubo T, Kushitani H, Sakka S, Kitsugi T and Yamamuro T. Solutions able to reproduce in vivo surface-structure changes in bioactive glass-ceramic. J. Biomed. Mater. Res. 1990; 24 : 721-34.

18. Gilderman SL, Silmara CS, Cristiane XR, Euler AS. Individual and combined effects of the elements $\mathrm{Zn}, \mathrm{Mg}$ and $\mathrm{Sr}$ on the surface reactivity of a $\mathrm{SiO} 2 \cdot \mathrm{CaO} \cdot \mathrm{Na} 2 \mathrm{O} \cdot \mathrm{P} 2 \mathrm{O} 5$ bioglass system. J. Non-Crystalline Solids. 2014; 386: 19-28.

19.

20. Havard H, Julia W, Anne K, Ursula H, Joachim A and Erich W. Ceramic TiO2 foams: Characterization of a potential scaffold. J European Ceramic Society. 2004; 24: 661-8.

21. Muthusamy P, Kandiah K, Palanisamy M, Venkatachalam R, Palanisami K. Synthesis, characterization and biological response of magnesium- substituted nanobioactive glass particles for biomedical applications. Ceramics International. 2013; 39: 1683-94.

22. Jones J R. Review of bioactive glass: From Hench to hybrids. J ActaBiomaterialia. 2013; 9: 4457-86. 
23. Siqueira RL, Peitl O, Zanotto ED. Gel-derived SiO2 -CaONa2O- P2O5 bioactive powders: synthesis and in vitro bioactivity. Mater Sci Eng. 2011;31:983-91.

24. Ma J, Chen C Z, Wang D G, Shi J Z. Textural and structural studies of sol-gel derived $\mathrm{SiO} 2-\mathrm{CaO}-\mathrm{P} 2 \mathrm{O} 5-\mathrm{MgO}$ glasses by substitution of $\mathrm{MgO}$ for $\mathrm{CaO}$, Mater. Sci. Eng. 2012; 30: 886-90.

25. Zhu Y, Li X, Yang J, Wang S, Gaob H and Hanagata N. Composition-structure-property relationships of the $\mathrm{CaO}-\mathrm{MxOy}-\mathrm{SiO} 2-\mathrm{P} 2 \mathrm{O} 5$ ( $\mathrm{M}=\mathrm{Zr}, \mathrm{Mg}, \mathrm{Sr}$ ) mesoporous bioactive glass (MBG) scaffolds. J Mater Chem. 2011; 21: 9208-18.

26. Innocenzi P. Infrared spectroscopy of sol-gel derived silica-based films: a spectra-microstructure overview. Journal of Non-Crystalline Solids. 2003; 2: 309-19.

27. Kalampounias A G. IR and Raman spectroscopic studies of sol-gel derived alkaline-earth silicate glasses. Bulletin of Materials Science. 2011; 34: 299-303.

28. Carter C B and Norton M G. Ceramic Materials: Science and Engineering, Chapter 7: complex crystal and glass structures, Springer Science \& Business Media. 2016; 766.

29. Deliormanlı A M and Yıldırım M.Sol-gel synthesis of 1393 bioactive glass powders containing therapeutic agents. J Australian Ceram Soc. 2016; 52: 9 - 19.

30. Bellucci D, Cannillo V, Sola A. A new bioactive glass composition for bioceramic scaffolds, J. Ceram. Sci. Technol. 2010; 1: 33-40.

31. Zhu Y, Shang F, Li B, Dong Y, Liu Y, Lohe M R, Hanagatad $\mathrm{N}$ and Kaske S.Magnetic mesoporous bioactive glass scaffolds: preparation, physicochemistry and biological properties J. Mater. Chem. 2013; 1: 1279-88.

32. Bellucci D, Sola A, Salvatori R, Anesi A, Chiarini L, Cannillo V. Sol-gel derived bioactive glasses with low tendency to crystallize: Synthesis, post-sintering bioactivity and possible application for the production of porous scaffolds. Materials Science and Engineering. 2014; 43: 573-86.

33. Du J, Xiang Y. Effect of strontium substitution on the structure, ionic diffusion and dynamic properties of 45S5 bioactive glasses, J. Non-Cryst. Solids. 2012; 358: 1059-71.

34. Salters V J M. Chapter 101: Elements; High field strength. 1998; 209-10.

35. Coelho M B and Pereira M M. Sol-gel synthesis of bioactive glass scaffolds for tissue engineering: effect of surfactant type and concentration. J Biomed Mater Res. Part B. 2005; 75: 451-6.

36. Donnell M D, Hill RG. Influence of strontium and the importance of glass chemistry and structure when designing bioactive glasses for bone regeneration, ActaBiomater. 2010; 6: 2382-5.

37. Shahrabi S, Hesaraki S, Moemeni S, Khorami M. Structural discrepancies and in vitro nanoapatite formation ability of sol-gel derived glasses doped with different bone stimulator ions. Ceram Int. 2011; 37: 2737-46.

38. Jones JR, Hench LL. Regeneration of trabecular bone using porous ceramics. Curr Opinion Sol St Mater Sci. 2003; 7 : 301-7.

39. Kokubo T, Fujita Y, Yamamuro T, Nakamura T, Kotani $\mathrm{S}$, Ohtsuki C. The bonding behavior of calcite to bone, J. Biomed. Mater. Res.1991; 25: 991-1003.

40. Aguiar H, Solla E L, Serra J, León P G, Almeida N, CachinhoS,Davim E J, Correia J, Oliveira J M, Fernandes $\mathrm{M} \mathrm{H}$. Orthophosphate nanostructures in SiO2-P2O5$\mathrm{CaO}-\mathrm{Na} 2 \mathrm{O}-\mathrm{MgO}$ bioactive glasses. J Non-Crystalline Solids.2008; 354: 4075-80.

41. Surovell T A and Stiner M C. Standardizing Infra-red Measures of Bone Mineral Crystallinity: an Experimental Approach. Journal of Archaeological Science. 2001; 28: 633-42.

42. Oliveira J M, Correia R N, Fernandes M H. Effects of $\mathrm{Si}$ speciation on the in vitro bioactivity of glasses. Biomaterials. 2002; 23: 371-9.

43. Singh R K, Srinivasan A. Bioactivity of SiO2-CaOP2O5-Na2O glasses containing zinc-iron oxide. Applied Surface Science. 2010; 256: 1725-30.

44. Geros R Z L. Apatites in biological systems, Prog. Crystal Growth Charact.1981; 4: 1-45

45. Balamurugan A, Balossier G, Kannan S, Michel J, Rebelo A H S, Ferreira J M F. Development and in vitro characterization of sol-gel derived $\mathrm{CaO}-\mathrm{P} 2 \mathrm{O} 5-\mathrm{SiO} 2$ ZnObioglass. ActaBiomater. 2007; 3: 255-62.

46. Atkinson I, Anghel E M, Predoana L, Mocioiu O C, Jecu L, Raut I, Munteanu C, Culita D, Zaharescu M. Influence of $\mathrm{ZnO}$ addition on the structural, in vitro behaviour and antimicrobial activity of sol-gel derived CaO-P2O5$\mathrm{SiO} 2$ bioactive glasses. Ceramics International. 2016; 42: 3033-45. 